\title{
The effect of allergic rhinitis on nasal septal body size
}

\author{
Alerjik rinitin nazal septal cisim büyüklüğü üzerindeki etkisi \\ Turhan San', Emre Gürkan², Barış Erdoğan³ ${ }^{3}$ Bülent Taşel ${ }^{4}$ \\ ${ }^{\prime}$ Department of Otolaryngology, Medeniyet University Göztepe Training and Research Hospital, Istanbul, Turkey \\ ${ }^{2}$ Department of Otolaryngology, Haydarpaşa Training and Research Hospital, Istanbul, Turkey \\ ${ }^{3}$ Department of Otolaryngology, Bolvadin Government Hospital. Afyonkarabisar, Turkey \\ ${ }^{4}$ Department of Radiology, Medeniyet University Göztepe Training and Research Hospital, Istanbul, Turkey
}

\begin{abstract}
Objective: To determine whether there is any radiologically detected effect of allergic rhinitis on nasal septal body (NSB) size.

Methods: Forty patients previously diagnosed with allergic rhinitis, and randomly selected thirty controls without allergic rhinitis were included in this study. Measurements of NSB size were performed in coronal plane paranasal sinus CT. Patients who had undergone nasal surgery, those with nasal polyposis, patients still using topical nasal spray, oral antihistamines, oral steroids and oral leukotrienes were excluded from the study.

Results: The average width of NSB was found $11.2 \mathrm{~mm}$ in patients with allergic rhinitis and $10.74 \mathrm{~mm}$ in patients without allergic. There was no significant difference between patients with and without allergic rhinitis in terms of NSB size on coronal plane paranasal sinus CT examination. Conclusion: Our results did not support the findings of previous studies. However, further randomized, prospective, controlled trials on larger series are necessary for making more precise interpretations.
\end{abstract}

Keywords: Allergic rhinitis, nasal septum, nasal septal body, nasal obstruction, computed tomography.

The nasal septal body (NSB) is a widened region of anterior nasal septum which is located superior to the inferior, and anterior to the middle turbinate. It consists of mucosa and a marked soft tissue overlying the cartilage and bone. Both cartilage and mucosa is thicker here compared to the other parts of the nasal septum. NSB plays an important role in the regulation of nasal airflow. Because it contains venous sinusoids, it is also called the septal turbinate. Because it contains venous sinusoids, it is also called as septal turbinate. Despite

\begin{abstract}
Özet
Amaç: Çalışmanın amacı nazal septal cisim büyüklüğü üzerine alerjik rinitin radyolojik olarak saptanan herhangi bir etkisinin olup olmadığını belirlemektir.

Yöntem: Daha önce alerjik rinit tanısı konmuş 40 hasta ve alerjik riniti olmayan randomize yöntemle seçilmiş otuz kontrol deneği bu çalışmaya dahil edildi. Koronal düzlem paranazal sinüs BT'sinde nazal septal cisim (NSC) boyutları ölçüldü. Nazal cerrahi geçirmiş hastalar, nazal polipleri olanlar, halen topikal nazal sprey, oral antihistaminik, oral steroid ve oral lökotriyen kullananlar çalışmaya alınmadı.

Bulgular: NSC'nin ortalama kalınlığının alerjik rinitli hastalarda 11.2 $\mathrm{mm}$, alerjik riniti olmayanlarda $10.74 \mathrm{~mm}$ olduğu saptandı. Koronal düzlemde paranazal sinüs BT incelemesinde NSC'nin büyüklügü açısından alerjik riniti olan ve olmayanlar arasında anlamlı farklılık yoktu.

Sonuç: Sonuçlarımız önceki çalışmaların bulgularını desteklememiştir. Ancak daha kesin yorumlar için daha fazla randomize, prospektif, kontrollü ve daha geniş serilere gerek vardır.
\end{abstract}

Anahtar sözcükler: Alerjik rinit, nazal septum, nazal septal cisim, nazal obstrüksiyon, bilgisayarlı tomografi.
Correspondence: Turhan San, MD. Eğitim Mah., 34722, Kadıköy,

İstanbul, Turkey.

e-mail: turhansan@gmail.com

Received: June 4, 2014; Accepted: July 18, 2014 of its important role in the regulation of nasal airflow, it is often ignored and may be confused with a high nasal septal deviation. In published studies, NSB has been mainly investigated histologically. Although there are a limited number of histological and anatomical studies related to NSB, to our best knowledge there are no study on radiological examination of NSB size in patients with allergic rhinitis. Here, our aim was to determine whether there is any radiologically detected effect of allergic rhinitis on NSB size. 


\section{Patients and Methods}

Our study was designed retrospectively and consisted of 70 patients. Forty patients who were admitted to the otorhinolaryngology polyclinic and previously diagnosed with allergic rhinitis, in addition to randomly selected thirty patients without allergic rhinitis were included in this study. Diagnosis of allergic rhinitis was confirmed with total $\operatorname{IgE}$ blood test, skin prick test and clinical findings. Coronal plane paranasal sinus CT scans of the patients in both groups were used to determine the thickness and location of NSB. We especially focused on the nasal septum. Paranasal sinus CT images were obtained using General Electric Optima 660 (GE Healthcare, Little Chalfont, Buckinghamshire, UK) machine as 128 slices and Toshiba Activation (Tokyo, Japan) machine as 16 slices.

Measurements of nasal septal body size were made as follows. As shown in Fig. 1, the widest part of the nasal septum was considered as the NSB in coronal plane paranasal sinus CT, and then its horizontal diameter was measured. Nasal septal body size difference between the two groups was calculated separately, and the results were compared with each other. Patients who had undergone nasal surgery, those with nasal polyposis, patients still using topical nasal spray, oral antihistamines, oral steroids and oral leukotrienes were excluded from the study. Independent samples t-test was used for the statistical analysis of parametric variables. For the analysis of categorical variables chi-square test was used.

\section{Results}

The study group consisted of 40 patients with allergic rhinitis (18 men and 22 women, aged between 15 and 74 years, median age 39 years). The control group consisted of 30 patients without allergic rhinitis (11 men and 19 women, aged between 18 and 70 years, median age 35 years). Variance analysis revealed no equal variances in study and control groups.

As shown in Table 1, the mean ( \pm SD) thickness of NSB in patients with or without allergic rhinitis was $11.2 \pm 1.56$ $\mathrm{mm}$ (range: $8.38-15.15$ ) and $10.74 \pm 1.49 \mathrm{~mm}$ (range: 8.80-15.07), respectively. There was no significant difference between patients with and without allergic rhinitis in terms of NSB size on coronal plane paranasal sinus CT examination $(\mathrm{p}=0.869)$. These findings were not in accordance with studies in the literature.

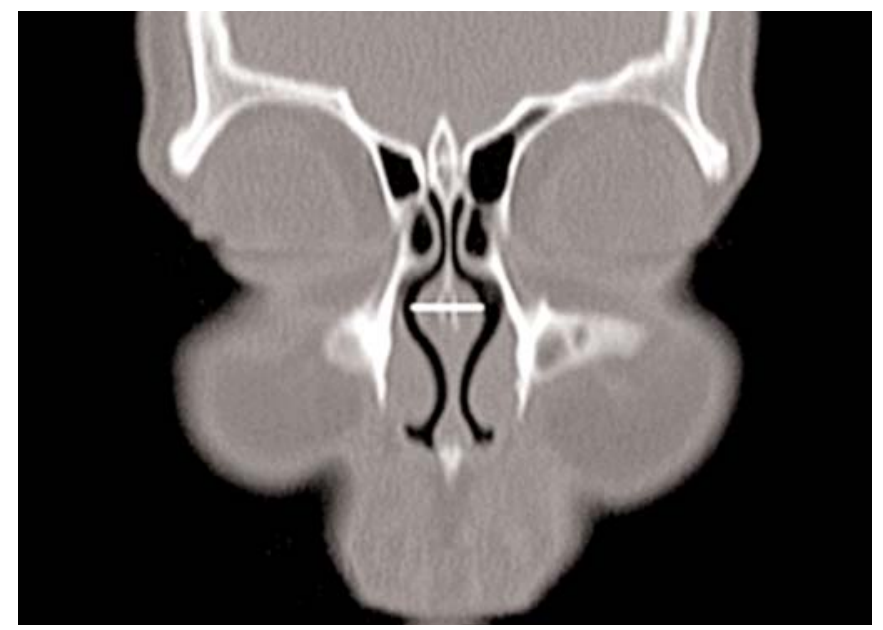

Fig. 1. Coronal plane paranasal sinus computed tomography slice showing nasal septal body.

\section{Discussion}

Nasal structures have important and specific functions. Especially the nasal septum supports the nasal structures and regulates nasal functions. The NSB is known as the thickest part of the nasal septum and it is closely related to internal nasal valve region. ${ }^{[1]}$ In a previous study, it has been reported as the mucosal thickness of the nasal septum. ${ }^{[2]}$ In endoscopic examination, NSB appears as a prominence along the anterior and the middle part of the nasal septum. Nasal mucosa contains numerous small veins, called venous sinusoids. Therefore it is named as venous erectile tissue or also the septal turbinate and was first described by Wustrow in $1951 .{ }^{[3]}$ Despite venous sinusoids there are in all structures of nasal cavity, this tissue is most intense in the inferior turbinate. With swelling of venous sinusoids nasal congestion occurs. The main reason of nasal obstruction in patients with allergic rhinitis is increased thickness of the NSB mucosa. Even NSB may be often misdiagnosed as high nasal septal deviation due to its swelling. The difference between the two is easily understood by palpation. With palpation the septal deviation is hard, but NSB is soft and compressible. NSB is a few millimeter-thick. There are a few studies on NBS in literature and this area has been neglected and overlooked until now. A previous radiographic and anatomic study showed that NSB has a fusiform shape, and located

Table 1. Mean NSB sizes of patients with and without AR.

\begin{tabular}{cccc}
\hline & Study group & Control group & $\mathbf{p}$ \\
\hline Mean \pm SD & $11.23 \pm 1.56$ & $11.17 \pm 1.49$ & 0.869 \\
\hline
\end{tabular}


anterior to the middle turbinate. Median width of NSB was 12.4 in $\mathrm{MRI}^{\left[{ }^{[4]}\right.}$ In another study, the average thickness of NSB was measured to be about $5 \mathrm{~mm} .{ }^{[5]}$ In our study, we investigated the effect of allergic rhinitis on NSB size and compared results with those of the control group. Although nasal airflow is regulated mainly by the nasal turbinate, NSB contains vasoerectile tissue and thus it may also effect nasal airflow. ${ }^{[6]}$ Both the nasal septal body and the inferior turbinate contain venous sinusoids and they are vasoerectile tissues. It is well known that the role of venous sinusoids is vasoexpansion. On nasal examination, the NSB appears as a swelling of the anterior septum, and it is localized superiorly in the nasal cavity above the inferior turbinate. There is a close relationship between NSB and the internal nasal valve. It has been recognized that a diminished internal nasal valve has a significant effect on nasal airflow and can cause nasal obstruction. In the majority of cases, nasal septal body is present bilaterally and it can be easily identified in the coronal plane paranasal sinus CT scans. The nasal septal body has been described in the literature using numerous terms including nasal septal swell body, intumescentia nasi anterior, septal turbinate, septal cavernous body, Kiesselbach's body, septal erectile tissue and anterior septal tubercle. ${ }^{[5,7]}$ In this study, we preferred to use the term nasal septal swell body due to its structural view on coronal plane paranasal sinus CT. Despite its many names, its exact role in nasal airway physiology has not been clearly defined so far. NSB affects airflow in a manner similar to the inferior turbinate due to its expansile vascular tissue. ${ }^{[5]}$ It has been radiologically proven that the anterior septal tissues have vasoactive expansile characteristics. It has been confirmed in several studies. ${ }^{[1,5,8-10]}$ But NSB compared with the inferior turbinate contains lesser amount of expansile tissue and thus its vasoactive capacity is not as much as the inferior turbinate. ${ }^{[11]}$ However, even minimal changes in NSB can have a considerable impact on nasal resistance. ${ }^{[8,12]}$ Therefore, it deserves more attention and investigation for understanding of its structure and function. If nasal septal body hypertrophy is accompanied with inferior turbinate hypertrophy in patients with allergic rhinitis, nasal obstruction may become more severe. They have similar effects on nasal physiology and may become hypertrophic in some cases. It is a well-known fact that the mucosa of nasal structures undergoes hypertro- phy in allergic situations. Recent studies have shown that the mucosa of nasal structures is edematous and thicker in allergic cases. But, our findings in the current study were different than previous studies. Nevertheless, we believe that this study contributes to the understanding of the function and structure of NSB. More studies are needed to evaluate the role of NSB in nasal obstruction.

\section{Conclusion}

There was no significant difference between patients with and without allergic rhinitis in terms of NSB size on coronal plane paranasal sinus CT examination. Our results did not support the findings of previous studies.

Conflict of Interest: No conflicts declared.

\section{References}

1. Gupta A, Brooks D, Stager S, Lindsey WH. Surgical access to the internal nasal valve. Arch Facial Plast Surg 2003;5:155-8.

2. Saunders MW, Jones NS, Kabala J, Lowe J. An anatomical, histological and magnetic resonance imaging study of nasal septum. Clin Otolaryngol Allied Sci 1995;20:434-8.

3. Wexler DB, Davidson TM. The nasal valve: a review of the anatomy, imaging and physiology. Am J Rhinol 2004;18:143-50.

4. Costa DJ, Sanford T, Janney C, Cooper M, Sindwani R. Radiographic and anatomic characterization of the nasal septal swell body. Arch Otolaryngol Head Neck Surg 2010;136:1107-10.

5. Wexler D, Braverman I, Amar M. Histology of nasal septal swell body (septal turbinate). Otolaryngol Head Neck Surg 2006;134: 596-600.

6. Cole P. The four components of the nasal valve. Am J Rhinol 2003;17:107-10

7. Arslan M, Muderris T, Muderris S. Radiological study of the intumescentia septi nasi anterior. J Laryngol Otol 2004;118:199-201.

8. Cole P. Biophysics of nasal airflow: a review. Am J Rhinol 2000;14 245-9.

9. Cole P, Haight JSJ, Naito K, Kucharczyk W. Magnetic resonance imaging of the nasal airways. Am J Rhinol 1989;3:63-7.

10. Yiğit O, Taşkın U, Acıoğlu E, Sisman AS, Hug GE. Histological evaluation of the nasal swell body in allergic patients. Turk Arch Otolaryngol 2013;51:41-4.

11. Cole P, Haight SJ, Cooper PW, Kassel EE. A computed tomography study of nasal mucosa: effects of vasoactive substances. J Otolaryngol 1983;12:58-60.

12. Marshall AH, Johnston MN, Jones NS. Principles of septal correction. J Laryngol Otol 2004;118:129-34.

This is an open access article distributed under the terms of the Creative Commons Attribution-NonCommercial-NoDerivs 3.0 Unported (CC BYNC-ND3.0) Licence (http://creativecommons.org/licenses/by-nc-nd/3.0/) which permits unrestricted noncommercial use, distribution, and reproduction in any medium, provided the original work is properly cited.

Please cite this article as: San T, Gürkan E, Erdoğan B, Taşel B. The effect of allergic rhinitis on nasal septal body size. J Med Updates 2014;4(2):49-51. 